\title{
SELECTED PROCEEDINGS
}

\section{International Conference for Philosophy, Psychiatry and Psychology 26 - 29 June 2014, Golden Sands Resort, Bulgaria}

\author{
MENTAL ILLNESS AND BRAIN DISEASE
}

Jeffrey D. Bedrick

Department of Psychiatry, Drexel University College of Medicine, Philadelphia, PA, USA

ПСИХИЧЕСКАЯ БОЛЕЗНЬ КАК БОЛЕЗНЬ МОЗГА

\author{
Джефри Д. Бедрик
}

Кафедра психиатрии, Дрексель Университет, Медицинский колледж Дрексель, Филадельфия, Пенсильвания, США

\begin{abstract}
It has become common to say psychiatric illnesses are brain diseases. This reflects a conception of the mental as being biologically based, though it is also thought that thinking of psychiatric illness this way will reduce the stigma attached to psychiatric illness. If psychiatric illnesses are brain diseases, however, it is not clear why psychiatry should not collapse into neurology, and some argue for this course. Others try to maintain a distinction by saying that neurology deals with abnormalities of neural structure while psychiatry deals with specific abnormalities of neural functioning. It is not clear that neurologists would accept this division, nor that they should. I argue that if we take seriously the notion that psychiatric illnesses are mental illnesses we can draw a more defensible boundary between psychiatry and neurology. As mental illnesses, psychiatric illnesses must have symptoms that affect our mental capacities and that the sufferer is capable of being aware of, even if they are not always self-consciously aware of them. Neurological illnesses, such as stroke or multiple sclerosis, may be diagnosed even if they are silent, just as the person may not be aware of having high blood pressure or may suffer a silent myocardial infarction. It does not make sense to speak of panic disorder if the person has never had a panic attack, however, or of bipolar disorder in the absence of mood swings. This does not mean psychiatric illnesses are not biologically based. Mental illnesses are illnesses of persons, whereas other illnesses are illnesses of biological individuals.
\end{abstract}

Key words: mental disorders, neurology, psychiatry, diagnosis

Folia Medica 2014; 56(4): 305-308

РЕЗЮМЕ

Copyright (C) 2014 Medical University, Plovdiv

Стало принято говорить, что психиатрические заболевания являются заболеваниями мозга. Это отражает концепцию психического как основаного на биологической процессах, хотя также считается, что такой взгяд на психические расстройства позволит ограничить стигматизацию психической болезни. Однако если психические расстройства являются заболеваниями головного мозга, не понятно почему психиатрию не следует редуцировать до неврологии, хотя некоторые и защищают такое развитие. Другие пытаются проводить различие, говоря, что неврология занимается аномалиями нейронной структуры в то время как психиатрия занимается конкретными нарушениями функционирования нервной системы. Не становится ясным неврологи принимают это разделение или нет. Я утверждаю, что если мы серьезно примем позицию, что психические расстройства являются психическими заболеваниями, можно сделать более оправданной границу между психиатрией и неврологией. Психиатрические заболевания должны иметь ментальные симптомы, которые оказывают влияние на наши умственные способности , и которые больной находится в состоянии понимать, даже если они не всегда сознательны. Неврологические заболевания, такие как инсульт или мултипленный склероз, могут вести за собой диагноз, даже если они находятся в латентном состоянии. К примеру, человек может не знать о своем высоком давлении крови или страдать “тихим" инфарктом миокарда. Нет смысла говорить о паническом расстройстве, если человек никогда в жизни не имел приступа паники, однако, или о биполярном расстройстве в отсутствие изменений настроения. Это не означает, что психиатрические заболевания не находятся на биологической основе. Психические заболевания являются заболеваниями личности, в то время как другие заболевания являются болезнями биологических индивидов.

Ключевые слова: психические разстройства, неврология, психиатрия диагноз

Folia Medica 2014; 56(4): 305-308

(C) 2014 Все права защищены. Медицинский университет, Пловдив

Article's history: Received: 29 Nov 2014; Received in a revised form: 3 Dec 2014; Accepted: 18 Dec 2014

*Correspondence and reprint request to: J. Bedrick, Department of Psychiatry, Drexel University College of Medicine,

27 E. Mt. Airy Avenue, Philadelphia, PA, USA;E-mail: jbedrick@drexelmed.edu; Tel.: (610)733-8978.

Drexel University College of Medicine, Philadelphia, PA, USA 


\section{INTRODUCTION}

It is common, in the United States at least, to say psychiatric illnesses are brain diseases. This reflects a conception of the mental as biologically based, or perhaps as even equivalent to the biological, though it is also thought that thinking of psychiatric illness in this way will reduce the stigma that is attached to psychiatric illness, and help have psychiatric illnesses come to be thought of as any other physical illness is.

If psychiatric illnesses are brain diseases, however, it is not clear why psychiatry should not collapse into neurology, and some have argued for this course. Others, such as the originators of the Research Domain Criteria $(\mathrm{RDoC})$ project at the NIMH, have tried to maintain a distinction by saying that neurology deals with abnormalities of brain, or neural, structure while psychiatry deals with abnormalities of neural functioning or of neural circuits. It is not clear that neurologists would accept this division, nor that they should. Nor is it clear that even the proponents of the RDoC project strongly support this distinction. Thomas Insel, the Director of the National Institute of Mental Health, for example, gave a lecture at the 2014 meeting of the American Psychiatric Association in New York this May that was titled "From Psychiatry to Clinical Neuroscience," which would seem to support both psychiatry and neurology as "clinical neurosciences."

In this paper I will argue against the collapse of psychiatric illnesses into brain diseases, and the collapse of psychiatry into neurology or clinical neuroscience. I will argue that if we take seriously the notion that psychiatric illnesses are mental illnesses, that we can draw a defensible boundary between psychiatry and neurology - and in doing so gain conceptual clarity about what psychiatric illnesses are and what makes particular illnesses psychiatric illnesses. So what is it to be a mental illness?

As mental illnesses, psychiatric illnesses must have symptoms that affect our mental capacities and the sufferer is capable of being aware of, even if they are not always self-consciously aware of them. Neurological illnesses on the other hand, such as stroke or multiple sclerosis, may be diagnosed even if they are silent (if the structural, or circuit, defects are located in areas that do not result in manifest symptoms), just as the person may not be aware of having high blood pressure or may even have suffered a so-called silent myocardial infarction. It does not, however, make sense to speak of panic disorder if the person has never had a panic attack, or of bipolar disorder in the absence of mood swings.

Once one has had such symptoms, a psychiatric illness can go into remission and not be associated with any current symptoms, although we might still say the person suffered from the illness. Thus schizophrenia may go into remission, or someone who suffers from alcohol dependence may become abstinent, though we might still diagnose the person involved as suffering from schizophrenia or alcohol dependence. If someone has biological vulnerabilities to a particular illness, on the other hand, but has not yet demonstrated the symptoms that mark the illness, we might say that he or she is at risk for the illness, vulnerable to the illness, or even in a prodromal stage, perhaps, but we would not say that he or she had the illness. A neurological - or for that matter endocrinological - illness might cause symptoms that appear psychiatric, but we do not consider the presence or absence of those symptoms necessary or sufficient conditions for making the diagnosis of the neurologic or endocrinologic illness. Hypothyroidism might lead to depression, but depression is not a necessary or sufficient condition for diagnosing the illness in the way that a panic attack is necessary to the diagnosis of panic disorder. Lupus may cause symptoms that appear psychiatric but we would not diagnose it as a psychiatric illness because the underlying pathology might well occur and be able to be diagnosed and categorized in the absence of any psychiatric symptoms.

Could we imagine a future point where we said there was a neural circuit abnormality of the same sort that caused panic disorder but which did not cause panic disorder, and so like the case for multiple sclerosis, lupus or stroke currently, we should not think of panic disorder as a specifically psychiatric diagnosis, but as the specific symptom caused by this sort of circuit disorder under particular circumstances? Could we imagine this for borderline or narcissistic personality disorder as well? I think it is hard to argue for this view across the broad spectrum of psychiatric diagnoses even if at first it might seem tempting in particular cases.

Some have argued that there are true psychiatric illnesses, such as schizophrenia or bipolar disorder, that have a biological basis, and then there are the other problems that the worried well consult us for, which are not truly illnesses. I suspect some proponents of the $\mathrm{RDoC}$ or of other purely 
biological approaches to psychiatric illness, might argue that the problems that look like they are problems of the worried well themselves have biological underpinnings. I think that those who object to the separation of psychiatric illnesses into two classes are correct, but would argue that this means all psychiatric illnesses are dependent upon the presence of mental symptoms for us to be able to make the diagnosis.

What if we were to find a particular abnormality of a neural circuit or circuits that proved to be inevitably associated with the development of a psychiatric illness, such as schizophrenia, some time later? Would we accept the neural circuit abnormality as sufficient for making the diagnosis? What if it were shown that some clinical intervention at this stage, before symptoms developed, had a beneficial effect on the course of the disorder or could even prevent it altogether? I think we might come to think of the presence of the abnormality as sufficient justification for clinical intervention, but I think the diagnosis itself would still depend on the presence of symptoms. In a similar way, Angelina Jolie or some other woman might choose to have mastectomies to prevent the development of breast cancer if they found they possessed a particular genetic marker for the development of the disease (or even a gene that we knew caused it). We might think this was justified and made clinical sense, but we would not say that she was having surgery for the removal of a breast cancer.

Could we imagine coming to think of the neural circuit abnormality as sufficient for the diagnosis? Can we imagine this for schizophrenia? Panic disorder? Borderline personality disorder? If we found someone with the disordered neural circuit but who never had symptoms would we want to say that they had the disorder but just didn't show symptoms? Or would we say that we had found a case that proved the disorder of neural circuitry we had found was not inevitably linked to the disorder? My sense is that we would say the latter. Mental effects remain central to our concept of psychiatric illness, and the link of neural circuits to psychiatric illness depends on what links we can establish between the neural circuits and mental symptoms.

This does not mean psychiatric illnesses are not biologically based. Mental phenomena depend on the brain, and not any immaterial substance or soul. But not all brain phenomena are mental. Breathing, for example, is controlled by the brain (utilizing input and feedback from other organs), but breath- ing is not a mental phenomenon. Although we can choose to control breathing consciously for a time, as when doing relaxation exercises or yoga, it will continue, in the absence of certain pathologies, even when our conscious attention stops. Thinking is a mental phenomenon, even though there is good evidence ranging from psychoanalytic research to modern experimental psychology to show that not all thought is conscious. What we see is that to count as a mental phenomenon, the activity must at times be one that we are (self)-consciously aware of and which we cannot conceive of occurring entirely without such self-consciousness. If all of our thinking occurred out of conscious awareness, we would not think of thinking, if you will pardon my putting it that way, as a mental phenomenon.

If psychiatric illnesses are mental illnesses, can we have animal models of psychiatric illness? I think there has been a general recognition that it is difficult to have animal models of psychiatric illness, if not an outright reluctance to accept them. It is interesting that the models that have been proposed, of depression, anxiety, intermittent explosive disorder, and for obsessive compulsive disorder have, obviously perhaps, been for affective and behavioral symptoms, where we are more likely to think animals may have some "mental" life. (Eric Kandel suggested that he might have found a mouse model for the negative symptoms of schizophreni in a talk at the APA several years ago, but I have not seen anything about this since.) The closer the animal to human, the more easily we accept the idea that animals might experience something close enough to what we experience to be able to provide a useful model of psychiatric symptoms or disorders. But even here I think the use of putative animal models is far from problem free. Rats that have been subjected to various painful conditions have been thought to show behaviours that suggest depression or anxiety, and it sometimes seems that we ought to accept that animals can have these feelings. But is depression merely affective? As much research on depression shows, and as cognitive therapy emphasizes, there are distorted cognitions and thought patterns in depression. Is this merely an epiphenomenon? Or are the animal models even more limited than we might have thought if we think of illnesses such as major depression or generalized anxiety disorder as disorders both of affect and cognition? I think the cognitive elements of depression and anxiety suggest that we be quite cautious here. Further, I have watched pet cats play with, or mock hunt 
things, that were not there, and I understand from cat owners that this is common, but I haven't heard people seriously suggest using cats as a model of psychosis. The limits that we feel apply to animal models of psychiatric illness support the idea that we do conceptualize psychiatric illnesses as mental illnesses rather than brain disorders.

Mental illnesses, we can now say, are illnesses of persons, whereas other illnesses are illnesses of biological individuals. Plants can suffer from viruses and other infections. Animals can suffer from a myriad of illnesses, but for the most part we do not consider them as suffering from mental illnesses. The extent to which we are willing to say of an animal that it is depressed is the extent to which we are willing to see that animal as a person, as being like us humans in important ways. We are more likely to do this in the case of hominids, who I think we truly do see as like us in relevant ways, or in the case of animals such as dogs, who by virtue of being our pets and participating in an important way in our lives we are perhaps willing to extend attributes of personhood to, and we would be much less likely to do this with wild canids, who are not part of our human families in the same way as their domesticated cousins are. (A recent article or book - but I do not remember where I saw this - argued that domestic dogs were in fact much more like us than wild canids, and that selective breeding over the millennia dogs have been domesticated had selected for exactly those characteristics that made dogs more human, amongst other characteristics selected for.)

What makes a biological individual a person? I cannot provide a definitive answer to this question here, but what I have argued above points to the link of personhood with the vulnerability to - or capacity for - mental illness. Personhood depends on the existence of an individual with a mental life. The existence of mental life is a necessary condition for the existence of mental illness. The existence of mental life, of mental phenomena, thus brings with it the possibility of mental illness. Vulnerability to mental illness is thus a mark of personhood. Whether we could imagine persons that were not at risk for mental illness is a topic for another paper. 